\title{
Article \\ Paclobutrazol Improves the Quality of Tomato Seedlings to Be Resistant to Alternaria solani Blight Disease: Biochemical and Histological Perspectives
}

\author{
Tarek A. Shalaby ${ }^{1,2, * \mathbb{D}, \text { Naglaa A. Taha }}{ }^{3}$, Dalia I. Taher ${ }^{4}$, Metwaly M. Metwaly ${ }^{5}$, Hossam S. El-Beltagi ${ }^{6,7, *(D)}$, \\ Adel A. Rezk ${ }^{3,6}$, Sherif M. El-Ganainy 1,3 (D), Wael F. Shehata ${ }^{6,8}$, Hassan R. El-Ramady ${ }^{9}$ \\ and Yousry A. Bayoumi 2,10
}

Citation: Shalaby, T.A.; Taha, N.A.; Taher, D.I.; Metwaly, M.M.; El-Beltagi, H.S.; Rezk, A.A.; El-Ganainy, S.M.; Shehata, W.F.; El-Ramady, H.R.; Bayoumi, Y.A. Paclobutrazol Improves the Quality of Tomato Seedlings to Be Resistant to Alternaria solani Blight Disease: Biochemical and Histological Perspectives. Plants 2022, 11, 425. https://doi.org/ $10.3390 /$ plants 11030425

Academic Editor: Alessandro Vitale

Received: 21 January 2022

Accepted: 1 February 2022

Published: 4 February 2022

Publisher's Note: MDPI stays neutral with regard to jurisdictional claims in published maps and institutional affiliations.

Copyright: (C) 2022 by the authors. Licensee MDPI, Basel, Switzerland. This article is an open access article distributed under the terms and conditions of the Creative Commons Attribution (CC BY) license (https:// creativecommons.org/licenses/by/ $4.0 /)$.
1 Department of Arid Land Agriculture, College of Agricultural and Food Science, King Faisal University, P.O. Box 400, Al-Ahsa 31982, Saudi Arabia; salganainy@kfu.edu.sa

2 Horticulture Department, Faculty of Agriculture, Kafrelsheikh University, Kafr El-Sheikh 33516, Egypt; yousry.bayoumi@agr.kfs.edu.eg

3 Agricultural Research Center, Plant Pathology Research Institute, Giza 12619, Egypt; naglaa_abdelbaset@yahoo.com (N.A.T.); arazk@kfu.edu.sa (A.A.R.)

4 Agricultural Research Center (ARC), Vegetable Crops Research Department, Horticulture Research Institute, Giza 12619, Egypt; daliataher1981@gmail.com

5 Agricultural Botany Department, Faculty of Agriculture, Kafrelsheikh University, Kafr El-Sheikh 33516, Egypt; metwalysalim@yahoo.com

6 Department of Agricultural Biotechnology, College of Agricultural and Food Science, King Faisal University, P.O. Box 400, Al-Ahsa 31982, Saudi Arabia; wshehata@kfu.edu.sa

7 Biochemistry Department, Faculty of Agriculture, Cairo University, Giza 12613, Egypt

8 Plant Production Department, College of Environmental Agricultural Science, El-Arish University, North Sinai 45511, Egypt

9 Soil and Water Department, Faculty of Agriculture, Kafrelsheikh University, Kafr El-Sheikh 33516, Egypt; hassan.elramady@agr.kfs.edu.eg

10 Physiology \& Breeding of Horticultural Crops Laboratory, Horticulture Department, Faculty of Agriculture, Kafrelsheikh University, Kafr El-Sheikh 33516, Egypt

* Correspondence: tshalaby@kfu.edu.sa (T.A.S.); helbeltagi@kfu.edu.sa (H.S.E.-B.)

Abstract: The production and quality of tomato seedlings needs many growth factors and production requirements besides controlling the phytopathogens. Paclobutrazol (PBZ) has benefit applications in improving crop productivity under biotic stress (Alternaria solani, the causal agent of early blight disease in tomatoes). In the current study, the foliar application of PBZ, at rates of 25, 50, and $100 \mathrm{mg} \mathrm{L}^{-1}$, was evaluated against early blight disease in tomatoes under greenhouse conditions. The roles of PBZ to extend tomato seedling lives and handling in nurseries were also investigated by measuring different the biochemical (leaf enzymes, including catalase and peroxidase) and histological attributes of tomato seedlings. Disease assessment confirmed that PBZ enhanced the quality of tomato seedlings and induced resistance to early blight disease post inoculation, at 7, 14, and 21 days. Higher values in chlorophyll content, enzyme activities, and anatomical features of stem (cuticle thickness) and stomata (numbers and thickness) were recorded, due to applied PBZ. This may support the delay of the transplanting of tomato seedlings without damage. The reason for this extending tomato seedling life may be due to the role of PBZ treatment in producing seedlings to be greener, more compact, and have a better root system. The most obvious finding to emerge from this study is that PBZ has a distinguished impact in ameliorating biotic stress, especially of the early blight disease under greenhouse conditions. Further studies, which consider molecular variables, will be conducted to explore the role of PBZ in more detail.

Keywords: anatomy; biotic stress; catalase; early blight; paclobutrazol; peroxidase; phytopathogens; disease index; antifungal; chlorophyll content 


\section{Introduction}

Tomato (Solanum lycopersicum L.) is one of the most valuable vegetable crops worldwide. The Egyptian cultivated area of tomato was 375,276 ha, with a productivity of $38.96 \mathrm{Mg} \mathrm{ha}^{-1}$ [1]. The highest Egyptian production of tomatoes during the last decade was 8.6 million metric tons in 2012 [2]. Globally, in 2019, the main producers of tomato included China, which produces alone about 63 million tons, $\approx 35 \%$, of the total (181 million ton), followed by India, Turkey, the USA, and Egypt producing 19, 12.8, 10.9, and 6.9 million tons, respectively [1]. High seedling quality and their transplantation are mutual practices in the fruitful production of the tomato for fast, sustainable establishing, together with enhancement of earliness, uniform maturity and total yield, as well as quality [3]. The lack of a pre-contracting system for tomato seedlings between the nursery and farmers led the nursery to produce seedlings in a large quantity, sometimes causing a wait for sales [4]. These seedlings may be exposed to damage if they are not transplanted into the field at the appropriate time. Therefore, it is helpful to extend the seedlings life in the nursery, while maintaining high quality without losses. Several compounds can inhibit height growth, hence, extending the life of vegetable seedlings, such as chlormequat chloride (CCC) and daminozide [5], as well as paclobutrazol [6-8].

Paclobutrazol (PBZ), a triazole-type plant growth regulator or retardant, is wellknown as anti-gibberellins. PBZ can block the conversion of ent-kaurene to ent-kaurenoic acid during biosynthesis pathway of gibberellin by inhibition of kaurene oxidase $[9,10]$. Foliar application of Paclobutrazol usually reduces shoot and root length by increasing the stiffness of the cell wall and decreasing cell wall expansion [11]. Several studies confirmed that applied PBZ improved various kinds of compatible solutes and osmo-protectants, such as proline, which increases the plant's tolerance to water deficits $[9,12]$. Many benefits of PBZ application have been intensively reported, including improving crop productivity, plant stress tolerance, fruit/grain quality, plant water relation, and membrane stability index $[13,14]$. In addition, PBZ prevents sucker re-growth in bananas [15], promoting fruit sets in many crops (such as olives) [16], as well as inhibiting the biosynthesis of gibberellin, early fruit set, and reduced stem growth [17]. Concerning the toxicity of PBZ, for living organisms, showed low toxicity via the dermal route in animals, whereas it caused moderate toxicity via human oral and inhalation routes. Based on the available researches, PBZ is considered unlikely to be genotoxic or carcinogenic to humans [18,19].

Fungal diseases are considered one of the core problems facing and affecting tomato seedlings in the nurseries. Among the pathogens that affect tomato seedlings are soil-borne (causing root decay or damping-off) and foliar diseases, including Alternaria solani and Phytophthora infestans, which reduce yield quality [20]. Among foliar pathogens, A. solani, which caused an early blight disease in tomatoes, is a highly destructive pathogen on both open field and greenhouse tomatoes [21,22]. A. solani causes infections on foliage, basal stems of transplants, stems of mature plants (stem lesions), and fruits (fruit rot) of tomato [23]. Early blight disease may cause crop losses of up to $78 \%$ to solanaceous crops [24].

Regardless of the promising results of chemical treatments in controlling fungal pathogens, phytotoxicity, and chemical residues are major problems that lead to environmental pollution and human health hazards.

Keeping the roles of PBZ under stress in view, the main aim of the present study is (1) to find out whether the foliar application of paclobutrazol has any growth regulatory outcomes on tomato seedlings under both normal and early blight stress disease, (2) to document the extending impact of the applied paclobutrazol handling of tomato seedlings in nurseries, and (3) to observe the biochemical and histological responses of tomato seedlings to paclobutrazol foliar application, under both control and biotic stress conditions. 


\section{Results}

\subsection{Pathogenic Ability of the Four A. solani Isolates on Tomato Plants}

An experiment was conducted to assess virulence of four $A$. solani isolates by using a susceptible tomato hybrid (Alissa $F_{1}$ ) under greenhouse conditions. While all of the four obtained isolates were pathogenic to tomato seedlings, causing identical early blight disease symptoms, isolate number $1\left(\mathrm{I}_{1}\right)$ was the greatest virulence isolate in the experiment (Table 1), compared with the other isolates. Isolate $\mathrm{I}_{1}$ had the highest disease index percent on tomato plants $(23.07,45.92$, and $80.5 \%$ after 7,14 , and 21 dpi, respectively). However, the other isolates were varied in their degrees of pathogenicity. Therefore, isolate $\mathrm{I}_{1}$ of the pathogen was chosen for the following studies. Differences in the pathogenicity of the tested pathogenic isolates may be due to their physiological and biochemical components. It may also relate to the genetic makeup of host variety and pathogen, as far as their interactions are concerned [25].

Table 1. Pathogenic ability of the isolates of Alternaria solani on tomato seedlings in pots under greenhouse conditions.

\begin{tabular}{cccc}
\hline \multirow{2}{*}{ Isolate No. } & \multicolumn{3}{c}{ Disease Index (\%) } \\
\cline { 2 - 4 } & 7 Days & 14 Days & 21 Days \\
\hline Isolate no. I1 & $23.05 \pm 0.89 \mathrm{a}$ & $45.92 \pm 2.36 \mathrm{a}$ & $80.50 \pm 2.39 \mathrm{a}$ \\
\hline Isolate no. I2 & $17.07 \pm 1.63 \mathrm{~b}$ & $38.07 \pm 1.62 \mathrm{~b}$ & $54.00 \pm 3.26 \mathrm{~b}$ \\
\hline Isolate no. I3 & $9.80 \pm 0.73 \mathrm{~d}$ & $29.44 \pm 1.62 \mathrm{~d}$ & $40.50 \pm 1.24 \mathrm{~d}$ \\
\hline Isolate no. I4 & $15.60 \pm 0.77 \mathrm{c}$ & $32.50 \pm 1.63 \mathrm{c}$ & $45.80 \pm 1.67 \mathrm{c}$ \\
\hline F. test & $* *$ & $*$ & $*$ \\
\hline
\end{tabular}

Where: I1, I2, I3m and I4 are the four isolates of Alternaria solani, which were used in the study, Mean values in each column, followed by the same letter, are not significant $(p<0.05),{ }^{*}$ and ${ }^{* *}$ indicating significant and highly significant, respectively.

\subsection{Impact of Paclobutrazol on the Linear Growth of A. solani}

The in vitro antifungal activity of paclobutrazol showed that all evaluated concentrations of PBZ indicated antifungal activity and significantly inhibited mycelial growth percentage of $A$. solani (Figure 1 and Table 2). All concentrations (25, 50, and $100 \mathrm{mg} \mathrm{L}^{-1}$ ) showed the highest reduction of mycelial radial growth $(2,2.7$, and $3 \mathrm{~cm})$, without significant differences in between, suggesting similar potency, compared to control treatment (without PBZ), which resulted no inhibition of mycelia growth $(9 \mathrm{~cm})$. The results showed that PBZ had the highest antagonistic effect against of $A$. solani (Figure 1 and Table 2). The reduction percentage of $A$. solani, due to PBZ applications, were the highest values, especially when using the rate of $100 \mathrm{mg} \mathrm{L}^{-1}(77.8 \%)$, without significant differences at 25 and $50 \mathrm{mg} \mathrm{L}^{-1}$ rates, 66.7 and $70 \%$, respectively.

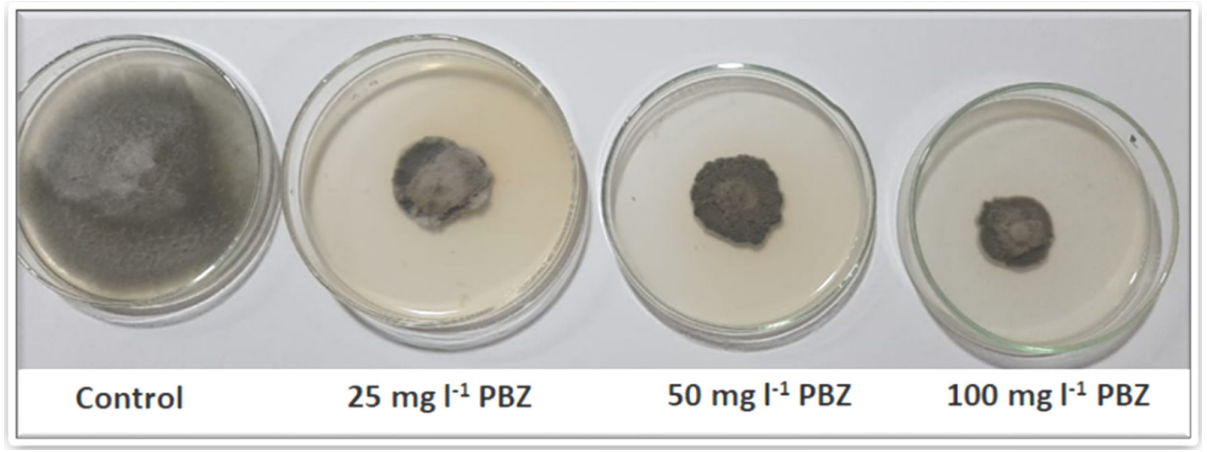

Figure 1. In vitro antifungal activity of paclobutrazol (PBZ) against Alternaria solani. The highest applied dose of PBZ $\left(100 \mathrm{mg} \mathrm{L}^{-1}\right)$ recorded the highest control of this disease, compared to the control. 
Table 2. The inhibition of Alternaria solani mycelial growth by PBZ application in different concentrations on PDA medium.

\begin{tabular}{|c|c|c|}
\hline Treatments & Mycelial Growth (cm) & Reduction Rate (\%) \\
\hline Control & $9.0 \pm 0.0 \mathrm{a}$ & $0.01 \pm 0.004 b$ \\
\hline PBZ $25 \mathrm{mg} \mathrm{L}^{-1}$ & $3.0 \pm 0.082 b$ & $66.7 \pm 0.735 \mathrm{a}$ \\
\hline PBZ $50 \mathrm{mg} \mathrm{L}^{-1}$ & $2.7 \pm 0.082 b$ & $70.0 \pm 2.450 \mathrm{a}$ \\
\hline PBZ $100 \mathrm{mg} \mathrm{L}^{-1}$ & $2.0 \pm 0.082 b$ & $77.8 \pm 1.563 \mathrm{a}$ \\
\hline F. test & $* *$ & $* *$ \\
\hline
\end{tabular}

Mean values in each column, followed by the same letter, are not significant $(p<0.05)$. PDA: potato dextrose agar medium. ${ }^{* *}$ indicating highly significant.

\subsection{Development of Early Blight Disease Due to PBZ Applications}

In general, in vitro experiment exogenous application with PBZ obviously reduced the of early blight intensity on tomato leaves, in comparison to the control seedlings, after 7, 14, and 21 days post-inoculation (dpi) (Figure 2 and Table 3). Although, an advanced rise was observed in both the disease incidence and disease severity on control tomato seedlings during the experiment. All PBZ applications significantly decreased the disease incidence (DI) and its severity (DS) percent, at 7, 14, and $21 \mathrm{dpt}$, until finishing the experiment. Applied PBZ at $25 \mathrm{mg} \mathrm{L}^{-1}$ was the most efficient treatment and had the lowermost DI and DS (\%) after the previously mentioned periods. It is worth mentioning that PBZ, at all doses, significantly reduced both the DI and DS percent at the three studied stages, and compared with the control treatment. In the same manner, all PBZ applications $(25,50$, and $100 \mathrm{mg} \mathrm{L}^{-1}$ ) showed the highest efficacy $(87.6,87.2$, and $84.3 \%$, respectively), compared to the untreated plants (Table 3 ).

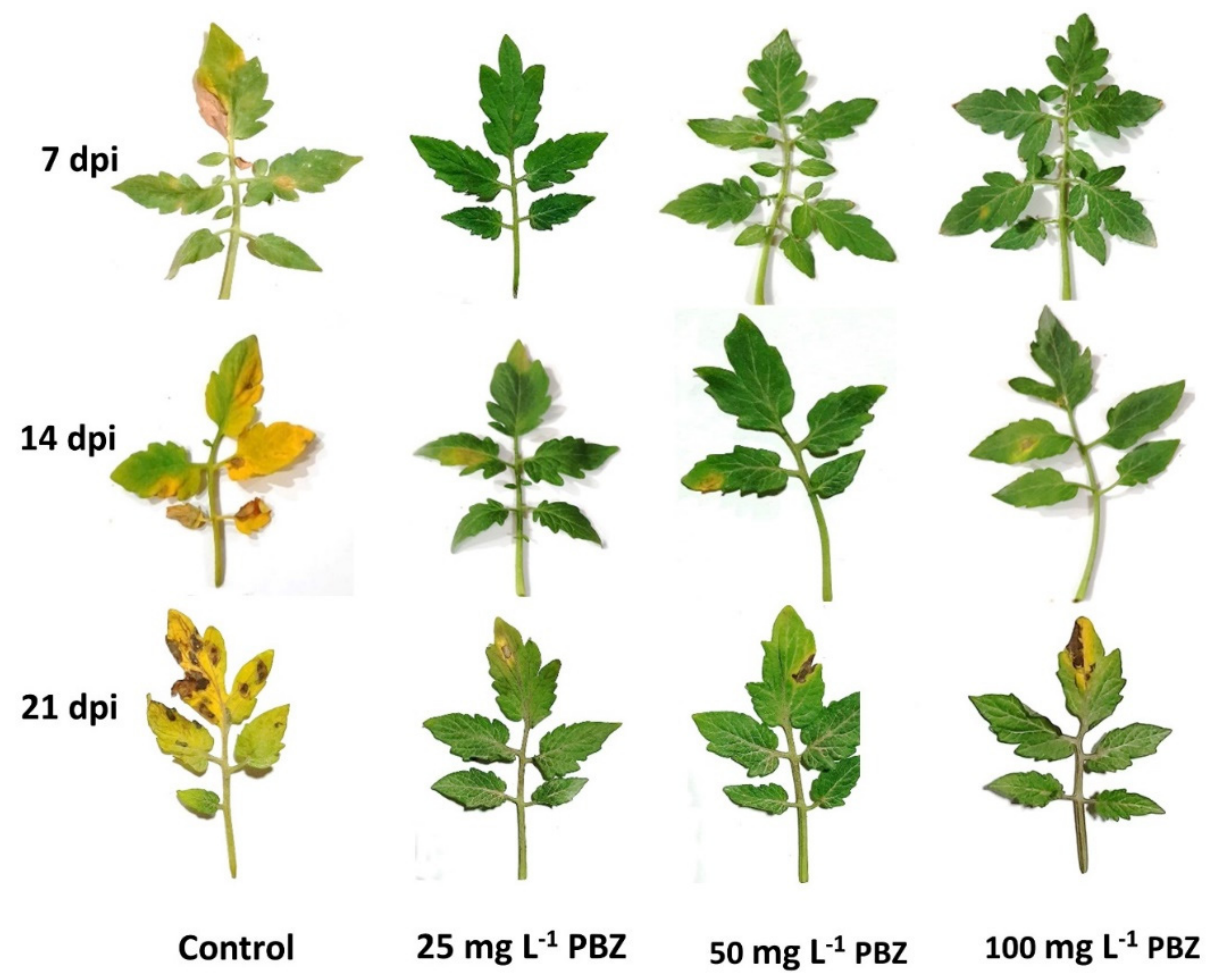

Figure 2. Effect of Paclobutrazol (PBZ) on progress symptoms of early blight disease on tomato seedlings under greenhouse conditions at 7, 14, and 21 dpi (day post inoculation). 
Table 3. Effect of PBZ applications on both disease incidence (DI) and disease severity (DS); \% of tomato early blight pathogen (A. solani) under greenhouse conditions at 7, 14, and $21 \mathrm{dpi}$ and an efficacy $\%$ at $21 \mathrm{dpi}$.

\begin{tabular}{|c|c|c|c|c|c|c|c|}
\hline \multirow{2}{*}{ Treatments } & \multicolumn{2}{|c|}{ After 7 Days } & \multicolumn{2}{|c|}{ After 14 Days } & \multicolumn{3}{|c|}{ After 21 Days } \\
\hline & DI (\%) & DS (\%) & DI (\%) & DS (\%) & DI (\%) & DS (\%) & Efficacy (\%) \\
\hline Control & $50.2 \pm 1.95 \mathrm{a}$ & $35.4 \pm 3.17 \mathrm{a}$ & $60.7 \pm 5.10 \mathrm{a}$ & $50.6 \pm 5.47 \mathrm{a}$ & $87.9 \pm 7.05 \mathrm{a}$ & $79.2 \pm 4.59 \mathrm{a}$ & $00.0 \pm 0.0$ \\
\hline $\mathrm{PBZ} 25 \mathrm{mg} \mathrm{L}^{-1}$ & $9.4 \pm 3.57 c$ & $3.6 \pm 0.95 b$ & $10.2 \pm 1.65 c$ & $5.5 \pm 1.25 \mathrm{~b}$ & $18.4 \pm 3.18 \mathrm{~b}$ & $9.8 \pm 1.58 \mathrm{~b}$ & $87.6 \pm 5.19$ \\
\hline PBZ $50 \mathrm{mg} \mathrm{L}^{-1}$ & $10.3 \pm 2.07 c$ & $3.6 \pm 0.89 b$ & $18.5 \pm 2.57 b$ & $8.1 \pm 1.98 b$ & $25.2 \pm 1.95 b$ & $10.1 \pm 1.99 \mathrm{~b}$ & $87.2 \pm 4.66$ \\
\hline PBZ $100 \mathrm{mg} \mathrm{L}^{-1}$ & $15.8 \pm 1.85 \mathrm{~b}$ & $3.6 \pm 1.05 \mathrm{~b}$ & $25.1 \pm 3.07 b$ & $10.3 \pm 2.05 b$ & $30.1 \pm 3.07 \mathrm{~b}$ & $12.4 \pm 2.17 \mathrm{~b}$ & $84.3 \pm 5.05$ \\
\hline F. test & $* *$ & $* *$ & $* *$ & $* *$ & $* *$ & $* *$ & - \\
\hline
\end{tabular}

Mean values in each column, followed by the same letter, are not significant $(p<0.05)$. ${ }^{* *}$ indicating highly significant.

\subsection{Response of Vegetative Growth and Chlorophyll Content to Applied PBZ}

To evaluate the response of tomato seedlings to applied doses of PBZ, different vegetative growth parameters, besides chlorophyll content, were measured after 10, 20, and 30 days from PBZ applications (during 2021) (Table 4). The seedlings treated with PBZ, after 10 days, represent the study of the role of applying different doses of PBZ, without infected seedlings and with $A$ solani as a control, whereas after 20 and 30 days, as infected seedlings. The commonly known impact of PBZ as a plant growth retarder is clear, due to its decreased seedling height. From Table 4, it can be seen that the seedling height was deceased by increasing the applied doses of PBZ, whereas, in general, seedling height values was increased from 10 to 30 days after foliar-applied PBZ. Although, the increasing rate of seedling height was the highest in control seedlings, as compared with the PBZ application in all stages (10, 20, and 30 days after applications). The applied dose of $50 \mathrm{mg} \mathrm{L}^{-1} \mathrm{PBZ}$ recorded, in general, the highest values of chlorophyll content, as well as after 10 or 20 or 30 days after foliar applied PBZ; then, the differences were not significant with the control treatment after only 10 days. Stem diameter values increased by an increasing period after PBZ application from 10 to 30, recording the highest value at dose of $100 \mathrm{mg} \mathrm{L}^{-1}$ $(0.336 \mathrm{~mm})$, compared to control seedlings, which resulted the lowest diameter in all stages. For seedling fresh weight, it was significantly influenced by treatments at all growth stages. After 10 days, the highest values were shown from control seedlings, compared to all PBZ applications. Nonetheless, all doses from PBZ produced the highest values of seedling fresh weight at 20 and 30 days after application, especially at a dose of $100 \mathrm{mg} \mathrm{L}^{-1}$. The most obvious observation to appear from the statistics comparison was the dry biomass per seedling, which was significantly differed after 10,20, and 30 days and the highest values were recorded from applied PBZ at dose of $100 \mathrm{mg} \mathrm{L}^{-1}$ ( 0.37 and $0.62 \mathrm{~g}$, respectively), after 20 and 30 days from application. Root fresh and dry weights were significantly affected by PBZ applications at the three growth stages. PBZ, at a rate of $100 \mathrm{mg} \mathrm{L}^{-1}$, resulted highest value of root fresh weight; however, a PBZ dose of $50 \mathrm{mg} \mathrm{L}^{-1}$ resulted in the highest value of root dry weight in most cases, compared to the other doses and control.

\subsection{Response of Enzyme Activities to Applied PBZ}

Two plant enzymes (catalase and peroxidase) were evaluated as bioindicators for survival tomato seedlings under biotic stress (Table 5). There was a highly significant relation between applied doses of PBZ and values of the studied enzymes, where the highest applied dose of PBZ (100 mg L $\left.{ }^{-1}\right)$ recorded the highest value of CAT (102.88) and POD (0.057) as $\mathrm{mM} \mathrm{H}_{2} \mathrm{O}_{2} \mathrm{~g}^{-1} \mathrm{FW} \mathrm{min}{ }^{-1}$, which did not significantly differ with PBZ at a dose of $50 \mathrm{mg} \mathrm{L}^{-1}$ in enzyme activities. These results confirmed that the foliar application of PBZ enhanced the cultivated tomato seedlings quality under biotic stress, through promoting and producing higher plant enzymes, which support cultivated seedlings under biotic and abiotic stresses. 
Table 4. Response of some vegetative growth parameters and chlorophyll content to PBZ doses after 10, 20, and 30 days from PBZ foliar application (during April 2021) (with/without infection by Alternaria solani).

\begin{tabular}{|c|c|c|c|c|c|c|c|}
\hline Treatments & $\begin{array}{l}\text { Seedling Height } \\
(\mathrm{cm})\end{array}$ & $\begin{array}{c}\text { Stem Diameter } \\
(\mathrm{mm})\end{array}$ & Seedling FW (g) & Seedling DW (g) & Root FW (g) & Root DW (g) & $\begin{array}{l}\text { Chlorophyll } \\
\text { Content (SPAD) }\end{array}$ \\
\hline \multicolumn{8}{|c|}{ After 10 days (Not infected seedlings by Alternaria solani) } \\
\hline Control & $13.24 \pm 1.50 \mathrm{a}$ & $0.207 \pm 0.021 \mathrm{a}$ & $2.65 \pm 0.501 \mathrm{a}$ & $0.30 \pm 0.006 \mathrm{a}$ & $0.86 \pm 0.14 \mathrm{a}$ & $0.085 \pm 0.005 \mathrm{a}$ & $28.4 \pm 2.35 \mathrm{a}$ \\
\hline PBZ $25 \mathrm{mg} \mathrm{L}^{-1}$ & $8.83 \pm 1.68 \mathrm{ab}$ & $0.215 \pm 0.015 \mathrm{a}$ & $1.62 \pm 0.452 b$ & $0.25 \pm 0.005 \mathrm{ab}$ & $0.47 \pm 0.05 b$ & $0.071 \pm 0.005 \mathrm{a}$ & $26.2 \pm 2.17 b$ \\
\hline PBZ $50 \mathrm{mg} \mathrm{L}^{-1}$ & $6.83 \pm 1.29 \mathrm{~b}$ & $0.238 \pm 0.011 \mathrm{a}$ & $1.48 \pm 0.363 \mathrm{~b}$ & $0.18 \pm 0.003 c$ & $0.44 \pm 0.07 \mathrm{~b}$ & $0.054 \pm 0.003 \mathrm{a}$ & $27.6 \pm 3.02 \mathrm{ab}$ \\
\hline $\begin{array}{l}\text { PBZ } 100 \mathrm{mg} \mathrm{L}^{-1} \\
\text { F. test }\end{array}$ & $\underset{* *}{9.56 \pm 1.55 \mathrm{ab}}$ & $\begin{array}{c}0.266 \pm 0.03 \mathrm{a} \\
\mathrm{NS}\end{array}$ & $\underset{*}{1.54 \pm 0.295 b}$ & $0.22 \pm \underset{* *}{0.005} \mathrm{bc}$ & $\underset{*}{0.36 \pm 0.07 b}$ & $\begin{array}{c}0.063 \pm 0.003 \mathrm{a} \\
\text { NS }\end{array}$ & $24.3 \pm \underset{* *}{ \pm} 1.95 c$ \\
\hline \multicolumn{8}{|c|}{ After 20 days (Infected seedlings by Alternaria solani) } \\
\hline Control & $14.75 \pm 2.17 \mathrm{a}$ & $0.275 \pm 0.007 \mathrm{a}$ & $3.05 \pm 0.524 \mathrm{ab}$ & $0.33 \pm 0.005 b$ & $0.94 \pm 0.18 c$ & $0.082 \pm 0.005 \mathrm{~b}$ & $28.8 \pm 3.05 c$ \\
\hline PBZ $25 \mathrm{mg} \mathrm{L}^{-1}$ & $11.94 \pm 1.66 \mathrm{~b}$ & $0.296 \pm 0.025 \mathrm{a}$ & $3.12 \pm 0.354 \mathrm{ab}$ & $0.34 \pm 0.007 \mathrm{~b}$ & $1.02 \pm 0.25 b$ & $0.088 \pm 0.007 \mathrm{~b}$ & $31.3 \pm 2.84 b$ \\
\hline PBZ $50 \mathrm{mg} \mathrm{L}^{-1}$ & $9.94 \pm 1.59 \mathrm{~b}$ & $0.299 \pm 0.034 \mathrm{a}$ & $2.88 \pm 0.441 b$ & $0.29 \pm 0.006 c$ & $0.89 \pm 0.18 c$ & $0.120 \pm 0.008 \mathrm{a}$ & $38.6 \pm 3.10 \mathrm{a}$ \\
\hline PBZ $100 \mathrm{mg} \mathrm{L}^{-1}$ & $11.22 \pm 2.09 \mathrm{~b}$ & $0.310 \pm 0.033 \mathrm{a}$ & $3.23 \pm 0.455 \mathrm{a}$ & $0.37 \pm 0.007 \mathrm{a}$ & $1.05 \pm 0.20 \mathrm{a}$ & $0.089 \pm 0.007 \mathrm{~b}$ & $33.9 \pm 1.99 \mathrm{~b}$ \\
\hline F. test & ** & NS & * & ** & $* *$ & $* *$ & $* *$ \\
\hline \multicolumn{8}{|c|}{ After 30 days (Infected seedlings by Alternaria solani) } \\
\hline Control & $27.33 \pm 3.17 \mathrm{a}$ & $0.254 \pm 0.028 \mathrm{~b}$ & $3.15 \pm 0.625 \mathrm{ab}$ & $0.42 \pm 0.008 \mathrm{~b}$ & $0.93 \pm 0.19 b$ & $0.091 \pm 0.009 \mathrm{c}$ & $24.9 \pm 2.25 c$ \\
\hline PBZ $25 \mathrm{mg} \mathrm{L}^{-1}$ & $11.79 \pm 1.29 \mathrm{~b}$ & $0.325 \pm 0.033 \mathrm{a}$ & $3.42 \pm 0.605 \mathrm{ab}$ & $0.57 \pm 0.009 \mathrm{ab}$ & $1.14 \pm 0.24 \mathrm{a}$ & $0.098 \pm 0.009 \mathrm{~b}$ & $32.1 \pm 2.19 \mathrm{~b}$ \\
\hline PBZ $50 \mathrm{mg} \mathrm{L}^{-1}$ & $9.86 \pm 1.45 \mathrm{~b}$ & $0.318 \pm 0.029 a$ & $2.96 \pm 0.385 b$ & $0.44 \pm 0.008 \mathrm{~b}$ & $0.95 \pm 0.23 \mathrm{~b}$ & $0.137 \pm 0.012 \mathrm{a}$ & $38.9 \pm 3.55 \mathrm{a}$ \\
\hline PBZ $100 \mathrm{mg} \mathrm{L}^{-1}$ & $11.48 \underset{* *}{ \pm} 1.88 \mathrm{~b}$ & $0.336 \pm \underset{* *}{0.017 \mathrm{a}}$ & $3.55 \pm \underset{* *}{0.550 \mathrm{a}}$ & $0.62 \pm 0.009 \mathrm{a}$ & $1.22 \pm \underset{* *}{0.026 a}$ & $0.132 \pm \underset{* *}{0} 0.015 \mathrm{a}$ & $32.7 \pm \underset{* *}{3} 3.06 \mathrm{~b}$ \\
\hline
\end{tabular}

Mean values in each column, followed by the same letter, are not significant $(p<0.05)$. Root fresh or dry weights were per one seedling, FW (fresh weight) and DW (dry weight), * and ** indicating significant and highly significant, respectively.

Table 5. Impact of applied treatments on enzyme activities (catalase, CAT, peroxidase, and POD) after 10 days form PBZ foliar application (after 10 days from PBZ application and without infection by Alternaria solani).

\begin{tabular}{|c|c|c|}
\hline Treatments & $\begin{array}{c}\text { POD } \\
\left(\mathrm{mM} \mathrm{H}_{2} \mathrm{O}_{2} \mathrm{~g}^{-1} \mathrm{FW} \mathrm{min}^{-1}\right)\end{array}$ & $\begin{array}{c}\text { CAT Activity } \\
\left(\mathrm{mM} \mathrm{H}_{2} \mathrm{O}_{2} \mathrm{~g}^{-1} \mathrm{FW} \mathrm{min}^{-1}\right)\end{array}$ \\
\hline Control & $0.012 \pm 0.011^{\mathrm{c}}$ & $2.82 \pm 0.429^{c}$ \\
\hline PBZ $25 \mathrm{mg} \mathrm{L}^{-1}$ & $0.032 \pm 0.020^{b}$ & $64.87 \pm 4.298^{b}$ \\
\hline PBZ $50 \mathrm{mg} \mathrm{L}^{-1}$ & $0.049 \pm 0.029 \mathrm{ab}$ & $90.30 \pm 5.556^{\mathrm{a}}$ \\
\hline PBZ $100 \mathrm{mg} \mathrm{L}^{-1}$ & $0.057 \pm 0.025^{\mathrm{a}}$ & $102.88 \pm 5.939^{a}$ \\
\hline F. test & $* *$ & $* *$ \\
\hline
\end{tabular}

Mean values in each column, followed by the same letter, are not significant $(p<0.05){ }^{* *}$ indicating highly significant.

\subsection{Response of Anatomical Features to Applied PBZ}

The internal structure of the tomato seedling stem is similar to the other dicotyledonous plants and built-up, essentially, of parenchyma ground tissue, including cortex tissue and pith tissue, regular vascular bundles, and medullary rays, which connect between the cortex and pith tissues. It is clear that, from the present data in Table 6 and Figure 3, the application of paclobutrazol has a positive impact on stem anatomical features, which led to enhancing most of investigated the anatomical measurements of tomato stem, especially the second dose $\left(50 \mathrm{mg} \mathrm{L}^{-1}\right)$, which increased the thickness values of the cuticle layer and tissues of epidermis, cortex, xylem, and phloem, as well as the diameter of stem crosssections and xylem vessels. These obtained results were compared with the control and other concentrations of PBZ used.

Stomata measurements have included stomata density and stomata dimensions (length and width). Data presented in Table 7 and Figure 4 showed that there was an increase in density of stomata, due to the application of PBZ, with various concentrations. These obtained results were compared to the control treatment. This increase of stomata density is due to the negative effect of PBZ on the leaf area, as well as the inhibition of it [26]. The highest values of stomata density were recorded in the application of the second concentration of PBZ, compared with other concentrations. Besides that, using PBZ with investigated concentrations enhanced the values of the stomata dimension (length and 
width), compared to the control treatment, due to the PBZ application stacking of the stomata, per area unit of leaves.

Table 6. Anatomical measurements of tomato stems, as affected by the application of various concentrations of PBZ substance (after 10 days from PBZ application and without infection by Alternaria solani).

\begin{tabular}{|c|c|c|c|c|c|c|}
\hline \multirow{2}{*}{\multicolumn{2}{|c|}{ Anatomical Measurements }} & \multicolumn{5}{|c|}{ Applied PBZ (mg L $\left.{ }^{-1}\right)$ Doses at the Second True Leaf Stage } \\
\hline & & Control & 25 & 50 & 100 & LSD 0.05 \\
\hline \multirow{5}{*}{$\begin{array}{c}\text { Thickness } \\
(\mu \mathrm{m})\end{array}$} & Cuticle & $4.37 \pm 0.69 \mathrm{~b}$ & $7.24 \pm 0.72 \mathrm{a}$ & $7.55 \pm 0.81 \mathrm{a}$ & $5.73 \pm 0.78 b$ & 1.42 \\
\hline & Epidermis & $33.70 \pm 2.09 \mathrm{~b}$ & $37.84 \pm 1.19 \mathrm{a}$ & $26.93 \pm 0.82 c$ & $27.22 \pm 0.48 \mathrm{c}$ & 3.46 \\
\hline & Cortex & $444.65 \pm 14.36 \mathrm{a}$ & $304.87 \pm 11.20 c$ & $435.64 \pm 8.66 \mathrm{a}$ & $396.43 \pm 34.04 b$ & 37.25 \\
\hline & Xylem & $387.53 \pm 8.58 c$ & $476.97 \pm 30.32 \mathrm{a}$ & $444.30 \pm 15.09 \mathrm{ab}$ & $415.46 \pm 10.36 \mathrm{bc}$ & 34.31 \\
\hline & Phloem & $95.00 \pm 4.80 c$ & $88.76 \pm 2.50 c$ & $155.48 \pm 6.80 \mathrm{a}$ & $109.03 \pm 6.11 \mathrm{~b}$ & 10.07 \\
\hline \multirow{2}{*}{$\begin{array}{l}\text { Diameter } \\
(\mu \mathrm{m})\end{array}$} & Xylem vessels & $60.87 \pm 2.00 \mathrm{a}$ & $46.47 \pm 1.46 \mathrm{a}$ & $58.42 \pm 2.01 \mathrm{a}$ & $53.58 \pm 2.25 \mathrm{a}$ & 11.70 \\
\hline & Stem & $2194.72 \pm 162.23 b$ & $2291.66 \pm 167.19 b$ & $2477.26 \pm 149.38 \mathrm{a}$ & $2581.89 \pm 138.94 \mathrm{a}$ & 70.40 \\
\hline
\end{tabular}

Mean values in each column, followed by the same letter, are not significant $(p<0.05)$.
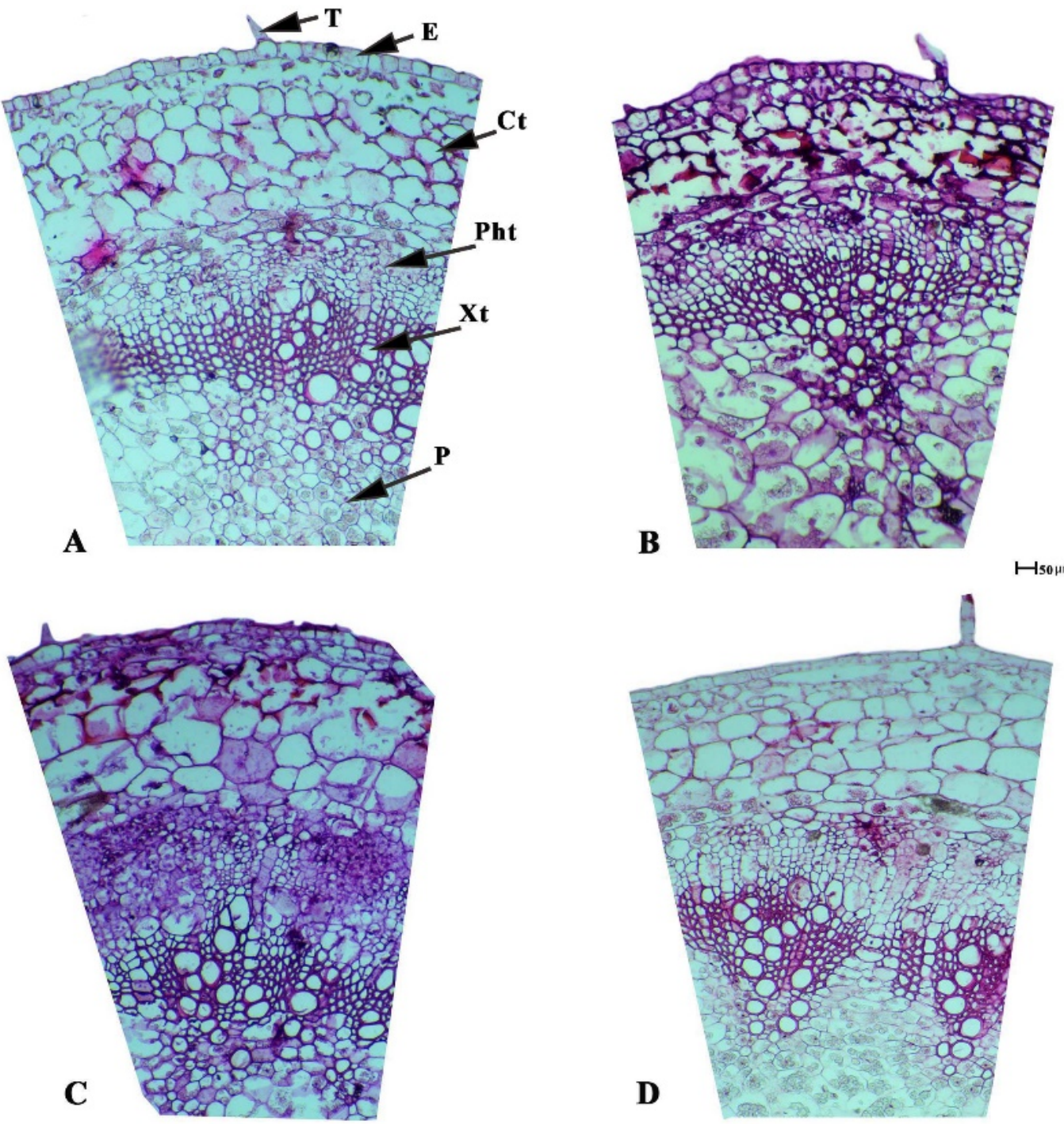

Figure 3. Transverse sections through the tomato stems, as affected by the application of various concentrations of PBZ substance, 10 days after applications, where (A-D) represent the treatments of the control, applied PBZ at 25, 50, and $100 \mathrm{mg} \mathrm{L}^{-1}$. The abbreviations: T (cuticle), E (epidermis), Ct (cortex tissue), Pht (phloem tissue), Xt (xylem tissue), P (pith), and MR (medullary rays). 
Table 7. Stomata measurements of tomato leaves, as affected by PBZ treatments (after 10 days from PBZ application and without infection by Alternaria solani).

\begin{tabular}{cccc}
\hline \multirow{2}{*}{ Treatments } & \multicolumn{3}{c}{ Stomata Measurements } \\
\cline { 2 - 4 } & Thickness $(\mu \mathrm{m})$ & Width $(\mu \mathrm{m})$ & Numbers \\
\hline Control & $42.09 \pm 1.83 \mathrm{~b}$ & $83.66 \pm 2.07 \mathrm{c}$ & $23.33 \pm 1.15 \mathrm{c}$ \\
PBZ 25 mg L $^{-1}$ & $38.16 \pm 1.60 \mathrm{c}$ & $88.89 \pm 1.80 \mathrm{~b}$ & $24.67 \pm 0.57 \mathrm{c}$ \\
PBZ 50 mg L $^{-1}$ & $46.21 \pm 0.65 \mathrm{a}$ & $93.01 \pm 1.47 \mathrm{a}$ & $36.00 \pm 1.00 \mathrm{~b}$ \\
PBZ 100 m L $^{-1}$ & $41.61 \pm 1.68 \mathrm{~b}$ & $86.14 \pm 1.58 \mathrm{bc}$ & $38.33 \pm 0.57 \mathrm{a}$ \\
LSD 0.05 & 2.86 & 3.29 & 1.63 \\
\hline
\end{tabular}

Mean values in each column, followed by the same letter, are not significant $(p<0.05)$.
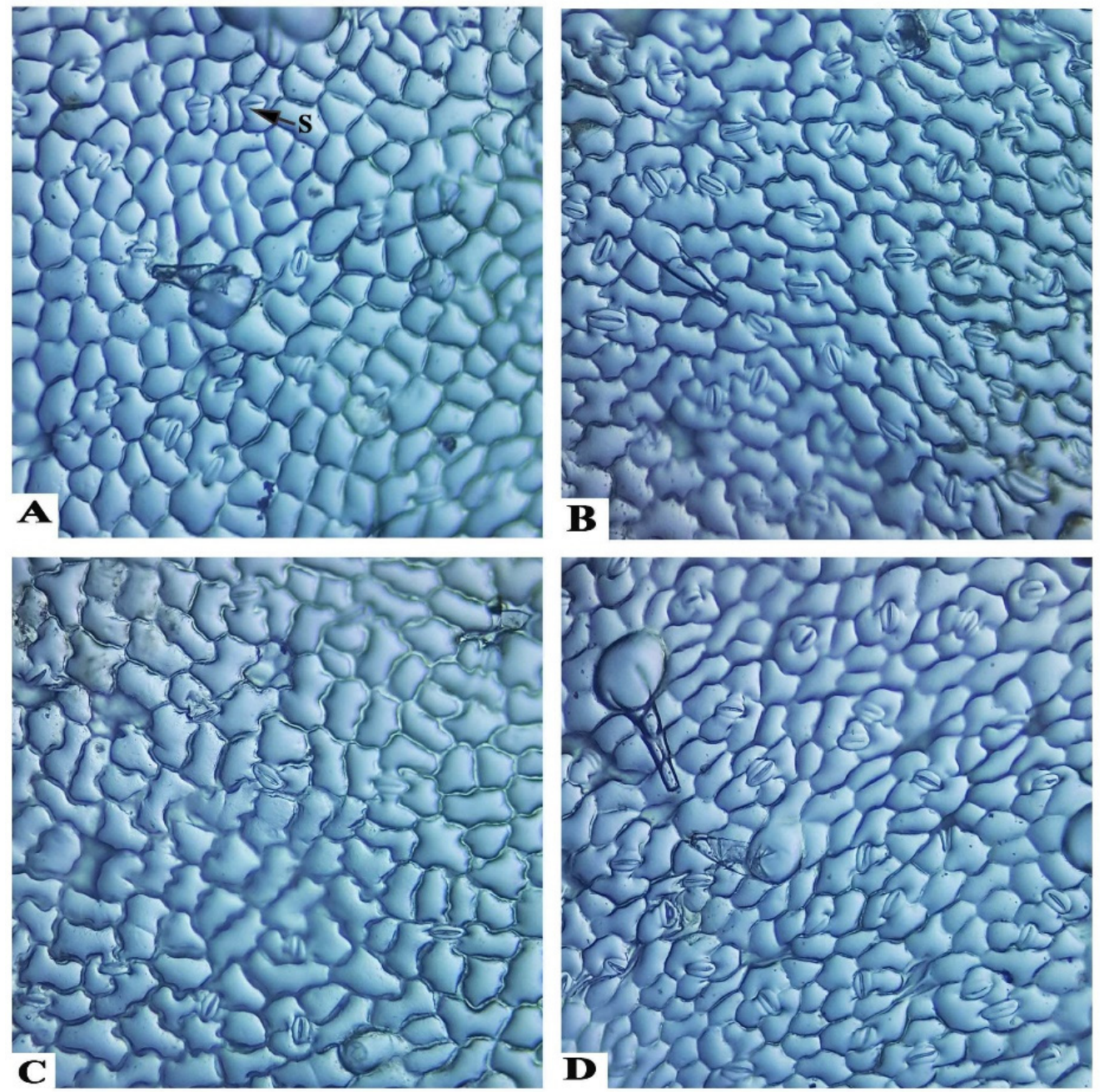

Figure 4. Photographs of stomata on adaxial (upper) surfaces of the tomato leaves, as affected by the application of various concentrations of PBZ substance, 10 days after applications, where (A-D) represent the treatments of the control, applied PBZ at 25, 50, and $100 \mathrm{mg} \mathrm{L}^{-1}$. The abbreviation: $\mathrm{S}$, stomata.

\section{Discussion}

High-quality tomato seedling production needs to save the required growth factors, including the environmental and practical issues. These issues may include controlling the pests and diseases, as well as proper agricultural practices (e.g., fertilization, irrigation, lighting, etc.). It is very important to produce vigorous tomato seedlings with a long shelf life, especially under intensive work in greenhouses, which sometimes needs a delay in transferring and transplanting seedlings into farming field [27]. This target will be more 
complicated under conditions of plant diseases, particularly the early blight. To extend the life and juvenility of tomato seedlings, without losses, many substances have been applied, such as chlormequat chloride (CCC), daminozide, and paclobutrazol. The role of applying different doses of PBZ to control the early blight, resulting from Alternaria solani, is investigated in the current study. After selecting the most aggressive, isolated inoculant of Alternaria solani, which had the highest disease index after 7, 14, and 21 days from the inoculation, different doses of applied PBZ were investigated on disease incidence and its severity of early blight pathogen (A. solani) on tomato seedlings under greenhouse conditions (Figures 1 and 2 and Tables 1-3).

Many studies published on the role of paclobutrazol in growing tomato seedlings, including applied different doses of PBZ (i.e., 50 and $100 \mathrm{mg} \mathrm{L}^{-1}$ ) through seed treatment or watering seedlings [28], production of tomato seedlings by applying PBZ (50, 100, and $150 \mathrm{mg} \mathrm{L}^{-1}$ ) using two tomato hybrids [29], and accelerating growth of tomato seedlings by applying 25, 50, and $100 \mathrm{mg} \mathrm{L}^{-1} \mathrm{PBZ}$ [30]; however, to our knowledge, there are no studies on the crucial role of PBZ against early blight (Alternaria solani). On the other hand, many studies reported on the reduction of vegetative growth via applied PBZ on many cultivated crops, such as potato [31], mango [32], Leonotis leonurus L. [33], and olive [16], as well as its potential under stress, i.e., drought $[13,14,34]$ and salinity $[9,35]$.

In the current study, in response to the question: what is the impact of paclobutrazol on the vegetative growth of tomato seedlings, a range of responses were elicited. The overall response to this question was very positive. The vegetative growth parameters were tested after 10, 20, and 30 days after the applied PBZ doses, where parameters after 10 days were without infected seedlings, but after 20 and 30 days, as infected seedlings. The direct cause of the increase in leaf darkness and greenness of treated seedlings with PBZ may be due to the increase in chlorophyll content. Surprisingly, PBZ was found to decrease the dry weight and chlorophyll content of seedlings after 10 days, but increased by increasing PBZ levels after 20 and 30 days. The increased chlorophyll content could be due to an increase in the activity of oxidative enzymes, which changed in the levels of carotenoids, ascorbate, and ascorbate peroxidase [31]. Plant enzymes, including CAT and POD, were increased by increasing applied doses of PBZ up to $100 \mathrm{mg} \mathrm{L}^{-1}$, recording 0.057 and 102.88, respectively (Table 5). This study produced results that corroborate the findings of a great deal of previous work in promoting growth of plants under stress by applying PBZ. PBZ improves plant tolerance against different stresses by increasing proline content and enzymatic antioxidants [14], increases fruit yield (due to the relatively stouter canopy of PBZ-treated plants), improving rooting system (which may increase the uptake of water and nutrients) [36], regulating photosynthetic capacity and delaying leaf senescence [37], improving the resistance against many plant pathogens [38], and acting as a systemic fungicide against several economically fungal diseases [39]. The mode of action of paclobutrazol may include the inhibition of gibberellic acid synthesis in plants, which reduces gibberellins level, slows cell division and elongation (without causing toxicity to cells), and increases cytokinin content, as well as the root activity and $\mathrm{C}$ : N ratio. Therefore, PBZ can delay senescence and extend the juvenility of seedlings, which increased the seedlings life without losses; additionally, it increased the resistance against most of pathogens in the nursery. Interestingly, few studies have reported the potential of paclobutrazol in improving the levels of chlorophyll, antioxidants, and proline contents under various biotic and abiotic stresses, as well as extending the plant growth cycle by delaying physiological maturity [40-43].

All anatomical features of the seedlings were influenced by the different doses of PBZ applied, particularly the stomata measures, including thickness, width, and numbers, which increased by increasing the applied doses of PBZ, up to $100 \mathrm{mg} \mathrm{L}^{-1}$ (Table 7). This increase in tomato stem diameter is achieved via the application of paclobutrazol treatment, due to its role to induce an increase in the vascular bundles' thickness, thicker cortex tissue, and wider pith tissue diameter, which is associated with larger medullary cells [44]. The highest value in the thickness of the stem cuticle $(7.55 \mu \mathrm{m})$ was achieved by 
applying $50 \mathrm{mg} \mathrm{L}^{-1} \mathrm{PBZ}$, which may support the resistance of tomato seedlings to early blight (Table 6). The highest numbers or values of stomata of numbers (38.33), thickness $(46.21 \mu \mathrm{m})$, and width $(93.01 \mu \mathrm{m})$ may lead to an increase in the efficiency of photosynthesis. Similarly, Tekalign and Hammes [31] stated that applying PBZ on potato leaves increased the anatomical parameters, i.e., thickness cortex, pith diameter, and size of the vascular bundles, and resulted in the thickest stems. This might be due to the radial enlargement of cells because of the decreased endogenous gibberellin activities in response to the treatment. In addition, using PBZ with investigated concentrations led to enhanced values of stomata dimension (length and width), compared to the control treatment, due to the fact that PBZ application stacked the stomata per area unit of leaves. This increase of stomata density is due to the negative effect of PBZ on the leaf area, as well as the inhibition of it [26].

\section{Materials and Methods}

\subsection{Isolation, Purification, and Identification of Causal Organism}

Four pathogenic fungi of $A$. solani were isolated from different tomato fields in Kafr ElSheikh governorate, Egypt. Briefly, tomato plants, showing typical symptoms of early blight disease, were collected from different locations. Infected leaves and stems were washed using tap water and cut into small parts $(5 \mathrm{~mm})$, sterilized using solution of $2 \%$ sodium hypo chloride for 2-3 min, then washed three times by sterilized distilled water (SDW). They were then dried between two layers of sterilized filter papers to remove excess water and plated onto petri dishes, $9 \mathrm{~cm}$ (in diameter), containing $15 \mathrm{~mL}$ potato dextrose agar (PDA) medium, amended with $100 \mathrm{mg} \mathrm{L}^{-1}$ streptomycin sulphate at $28 \pm 2{ }^{\circ} \mathrm{C}$ for 7 days [45]. The hyphal tip technique was used to purify the developed fungal cultures. Four isolates were characterized as $A$. solani, based on the morphological characters counting conidia size, number of longitudinal and transverse septa, and length of a beak [46]. Then, the four isolates were assured as $A$. solani, based on their pathogenicity and typical early blight disease symptoms on tomato plants.

\subsection{Pathogenicity Test}

Pathogenicity test of four $A$. solani isolates were confirmed on a highly susceptible hybrid of tomato (Alisa $\mathrm{F}_{1}$ hybrid) in pot trials under greenhouse conditions. Shortly, mycelial mats were harvested from seven-day old cultures of $A$. solani, then milled in $100 \mathrm{~mL}$ sterilized distilled water using sterilized mortar; it was filtered and put in a test tube, according to [47]. Thereafter, spore suspensions $\left(10^{6}\right.$ spores $\left.\mathrm{mL}^{-1}\right)$ were prepared for each of the four isolates in sterilized water. At 40 days old, tomato transplants were sprayed with tested inoculum of $A$. solani isolates, as spore suspension $\left(30 \mathrm{~mL} \mathrm{plant}^{-1}\right)$, while control plants were treated with same amount of distilled water. Inoculated plants were kept under polythene bags for $48 \mathrm{~h}$ to raise humidity and then incubated under greenhouse conditions. Disease index (DI\%) was assessed and results were recorded three times frequently $(7,14$, and 21 days post-inoculation (dpi)) to detect development of early blight disease. In this trial, six replicates were used; each replicate contains five pots $(20 \mathrm{~cm}$ diameter) with two plants in each pot.

\subsection{Antifungal Activity}

In vitro antifungal activities of PBZ were evaluated by the agar diffusion technique [48]. Briefly, three concentrations of $\operatorname{PBZ}\left(25,50\right.$, and $\left.100 \mathrm{mg} \mathrm{L}^{-1}\right)$, besides the control, were mixed in proper volumes, individually concentrate with $100 \mathrm{~mL}$ of the PDA medium, in sterilized Petri dishes to find required concentration. The negative control was sterilized with PDA medium. Then, the pre-prepared Petri dishes were inoculated with $5 \mathrm{~mm}$ diameter mycelial mass of freshly prepared culture of the pathogen $\left(\mathrm{I}_{1}\right.$ isolate), incubated at $27 \pm 1{ }^{\circ} \mathrm{C}$, and fungal growth was recorded for 7 days post-inoculation (dpi). The 
whole experiment used six replications for all treatments. The inhibition percentage of the mycelial growth has been determined using this equation:

$$
\text { Inhibition }(\%)=\frac{C-T}{C} \times 100
$$

where " $C$ " shows the mycelial growth in negative control dish, and " $T$ " show the mycelial growth in different treatments.

\subsection{Plant Materials and Growth Conditions}

This study was carried out in a nursery of the Faculty of Agriculture, April 2021, Kafrelsheikh University in Kafr El-Sheikh governorate, to examine the extending of tomato seedlings life using different doses of PBZ. Paclobutrazol was obtained from Shoura Company for chemicals, Cairo, Egypt, as super coltar 25\% PBZ. Paclobutrazol was dissolved in water to make solutions of four concentrations that have been used in the present study (i.e., 0, 25, 50, and $100 \mathrm{mg} \mathrm{L}^{-1}$ ). Throughout the current study, tomato genotype (Solanum lycopericum L.-Alissa $\mathrm{F}_{1}$ hybrid), which was more susceptible to early blight disease, was used as an experiential plant. Tomato seeds were obtained from the Nunhems Netherlands BV Company, Nunhem, Netherlands and sown in seedling trays in the nursery of a protected cultivation center, Faculty of Agriculture, Kafrelsheikh University, Egypt. Styrofoam trays, with 209 compartments, were filled with a mixture of coco peat: vermiculite (1:1 as $v / v)$. Treatments were arranged in six replicates; each replication was one tray per treatment (209 cells). All trays were planted manually, with 209 seeds per tray, and covered with the above-mentioned media. After sowing, the trays were put in a plastic house with temperatures ranging from 20 to $30^{\circ} \mathrm{C}$. Trays were watered every $2-3$ days using a sprinkler system to maintain substrate at field capacity. During the growth of the seedlings, they were fertilized one time in each trial, after over emergence by a soluble compound fertilizer.

At the second true leaf growth stage, seedlings were sprayed with four treatments of paclobutrazol $\left(0,25,50\right.$, and $100 \mathrm{mg} \mathrm{L}^{-1} \mathrm{PBZ}$. After 10 days from PBZ applications, tomato seedlings were sprayed with a spore suspension of $A$. solani. inoculum $\left(10^{6}\right.$ spores $\left.\mathrm{mL}^{-1}\right)$, as $250 \mathrm{~mL}$ seedling tray ${ }^{-1}$, whereas the similar amount of distilled water was sprayed on the control seedlings. The most aggressive isolate of $A$. solani (isolate number $1, \mathrm{I}_{1}$ ) was used in our study. Tomato seedlings were sprayed using a manual pump sprayer, with an appropriate flow rate, until runoff.

Disease incidence (DI) of early blight was evaluated three times after inoculation, at 7 , 14 , and 21 days post inoculation (dpi). At the 7th, 14th, and 21st dpt, disease severity (DS) of the typical symptoms of early blight disease was assessed [47]. For all treatments, six replications were investigated.

\subsection{Assessment of Vegetative Growth and Chlorophyll Content}

Vegetative growth parameters of tomato seedlings were assessed for all treatments after 10,20, and 30 days from PBZ application. The growth parameters included seedling height $(\mathrm{cm})$, stem diameter $(\mathrm{mm})$, and fresh and dry weights of seedling and roots $(\mathrm{g})$ per one seedling. Dry mass was measured after drying at $65^{\circ} \mathrm{C}$ for $48 \mathrm{~h}$. Total chlorophyll content was recorded in the fully expanded seedling leaf, via the SPAD-501 chlorophyll meter (SPAD-501, Konica Minolta, Tokoyo, Japan), according to [49].

\subsection{Enzyme Activities}

For enzyme analysis, after 10 days from foliar application of PBZ, samples from fresh leaves tissues were used to measure the total soluble enzymes activity of Catalase (CAT) activity, according to [50], and peroxidases (POD), according to [51].

\subsection{Anatomical Measurements}

For anatomical investigation, transverse sections were taken from the tomato seedlings ten days after PBZ application. The selected treatments samples used the second internode 
of the stem from the apex. The chosen samples were killed and fixed for $48 \mathrm{~h}$ in (FAA) solution (10 mL formalin, $5 \mathrm{~mL}$ glacial acetic acid, and $85 \mathrm{~mL}$ ethyl alcohol $70 \%$ ), then washed in ethyl alcohol $70 \%$ twice. The dehydration of the samples was performed by passing it in a series of concentrations of ethyl alcohol, followed by embedding it in paraffin wax of $54{ }^{\circ} \mathrm{C}$ melting point. Sectioning, at a thickness of $12(\mu \mathrm{m})$, was done with a rotary microtome (model Leica RM 2125, Leica company, Wetzler, Germany)), followed by staining with safranin and light green. The samples were cleared in xylene and mounted in Canada balsam, prepared for microscopic examination [52]. Five reading from each slide were examined with electric microscope (Leica DM LS, Wetzler, Germany) and digital camera (Leica DC300, Wetzler, Germany), then photographed. The histological manifestations were calculated using Leica IM 1000 image management software. Leica software was calibrated utilizing a $1 \mathrm{~cm}$ stage micrometer, scaled at $100 \mu \mathrm{m}$ increments (604364 Leitz Wetzler, Germany) at $10 \times$ magnification. The chosen sections were examined microscopically to detect histological features to follow the changes occurring in the stems of tomato plants, as affected by the application of three different concentrations of PBZ, i.e., 25, 50, and $100 \mathrm{mg} \mathrm{L}^{-1}$. The histological features in the stem sections are the vascular bundle dimensions (thickness and width), xylem vessels diameter, and thickness of xylem and phloem tissue. One developed mature leaf was randomly chosen after 10 days from PBZ application. Upper epidermis imprints were formed from the middle of each leaflet blade using Cyanoacrylate adhesive (Amir Alpha, www.amazon.eg, accessed on 21 January 2022). A drop of the adhesive was placed on a microscopic slide and quickly pressed on the desired spot of a leaflet, baked by hand. After hardening, the adhesive forms replica of the leaf surface; it was gently peeled off, and the slides were kept for microscopic measurements [53]. Each imprint was examined and photographed with an electric microscope with a digital camera; from each photograph, the number of contained stomata were counted in square microns $\left(\mu \mathrm{m}^{2}\right)$ using the Leica IM 1000 image management software, Wetzler, Germany).

\subsection{Statistical Analyses}

All the obtained results of the experiments were tabularized and statistically analyzed using analysis of variance method, by means of Co-STAT computer software package, IBM, Armonk, NY, USA, and Duncan's multiple range test was used to compare between means of treatments [54].

\section{Conclusions}

Healthy and vigorous tomato seedlings are necessary for tomato production, where strong seedlings can support plant productivity in the farming field. The extending of seedling life is also considered an important agro-practice in several nurseries, especially under intensive work to avoiding seedlings losses or damages. The current study was carried out to evaluate whether applying different doses of PBZ can enhance the growth and quality of tomato seedlings, as well as suppress the early blight under greenhouse conditions. The results of this research support the idea that PBZ is not only a plant retardant or plant growth regulator but also a stress ameliorant. Applying PBZ enhanced tomato seedlings quality, as the vegetative growth, through the inhibition of stem cell elongation, reduced the length of internodes of the stem, as well as the size and volume of leaves, and increased chlorophyll production. This is the first study on PBZ that examines the associations between applied doses of PBZ on tomato seedling resistance to the early blight pathogen (A. solani). Taken together, these findings suggest the role of PBZ in promoting the life of tomato seedlings, with high quality and without losses. The findings of this investigation complement those of earlier studies in the field of tomato seedling production, particularly under different stresses in particular biotic ones. These findings raised important theoretical issues that have a bearing on the environmental dimension of PBZ: are there any ecotoxicological impacts of applied PBZ on the agroecosystem? 


\begin{abstract}
Author Contributions: Conceptualization and visualization, T.A.S., H.S.E.-B., N.A.T., and D.I.T.; resources, M.M.M., A.A.R., W.F.S., S.M.E.-G., H.R.E.-R., and Y.A.B.; methodology, M.M.M., A.A.R., W.F.S., S.M.E.-G., H.R.E.-R., and Y.A.B.; software, T.A.S., H.S.E.-B., N.A.T., and D.I.T.; validation, M.M.M., A.A.R., W.F.S., S.M.E.-G., and H.R.E.-R.; investigation, T.A.S., H.S.E.-B., N.A.T., and D.I.T.; data curation, M.M.M., A.A.R., W.F.S., S.M.E.-G., H.R.E.-R., and Y.A.B.; writing-original draft preparation, T.A.S., H.S.E.-B., N.A.T., and D.I.T.; writing-review and editing, T.A.S., H.S.E.-B., N.A.T., D.I.T., M.M.M., A.A.R., W.F.S., S.M.E.-G., H.R.E.-R., and Y.A.B.; funding acquisition, H.S.E.-B., T.A.S., A.A.R., and W.F.S. All authors have read and agreed to the published version of the manuscript.

Funding: Deanship of Scientific Research, Vice Presidency for Graduate Studies, and Scientific Research, King Faisal University, Saudi Arabia: grant no. AN00050.
\end{abstract}

Institutional Review Board Statement: Not applicable.

Informed Consent Statement: Not applicable.

Data Availability Statement: Not applicable.

Acknowledgments: Authors acknowledge the Deanship of Scientific Research Vice Presidency for Graduate Studies and Scientific Research, at King Faisal University, for the financial support, under annual research project (grant no.AN00050).

Conflicts of Interest: There is no conflict of interest among the authors.

\title{
References
}

1. FAOSTAT. Tomato Production in 2019, Crops/Regions/World List/Production Quantity (Pick Lists); Corporate Statistical Database (FAOSTAT); UN Food and Agriculture Organization: Rome, Italy, 2020.

2. Statista. Tomatoes Production Volume in Egypt from 2010 to 2019 (In Million Metric Tons). Available online: https://www. statista.com/statistics/1066432/egypt-tomatoes-production-volume/ (accessed on 12 December 2021).

3. Hoffmann, A.B.; Poorter, H. Avoiding bias in calculations of relative growth rate. Ann. Bot. 2002, 80, 37-42. [CrossRef] [PubMed]

4. Kelley, W.T.; Boyhan, G. Commercial Tomato Production Handbook; UGA Cooperative Extension Bulletin 1312; University of Georgia: Athens, GA, USA, 2017.

5. Wanderley, C.D.; de Faria, R.T.; Ventura, M.U.; Vendrame, W. The effect of plant growth regulators on height control in potted Arundina graminifolia orchids (Growth regulators in Arundina graminifolia). Acta Sci. Agron. 2014, 36, 489-494. [CrossRef]

6. Koukourikou-Petridou, M.A. Paclobutrazol affects the extension growth and the levels of endogenous IAA of almond seedlings. Plant Growth Regul. 1996, 18, 187-190. [CrossRef]

7. Aphalo, P.; Rikala, R.; Sanchez, R.A. Effect of CCC on the morphology and growth potential of containerised silver birch seedlings. New For. 1997, 14, 167-177. [CrossRef]

8. Ellis, G.D.; Knowles, L.O.; Knowles, N.R. Increasing the Production Efficiency of Potato with Plant Growth Retardants. Am. J. Potato Res. 2020, 97, 88-101. [CrossRef]

9. Detpitthayanan, S.; Romyanon, K.; Songnuan, W.; Metam, M.; Pichakum, A. Paclobutrazol Application Improves Grain 2AP Content of Thai Jasmine Rice KDML105 under Low-Salinity Conditions. J. Crop Sci. Biotechnol. 2019, 22, 275-282. [CrossRef]

10. Abdalla, N.; Taha, N.; Bayoumi, Y.; El-Ramady, H.; Shalaby, T.A. Paclobutrazol applications in agriculture, plant tissue cultures and its potential as stress ameliorant, A Mini-Review. Environ. Biodivers. Soil Secur. 2021, 5, 245-257. [CrossRef]

11. Yang, T.; Davies, P.J.; Reid, J.B. Genetic dissection of the relative roles of auxin and gibberellin in the regulation of stem elongation in intact light-grown peas. Plant Physiol. 1996, 110, 1029-1034. [CrossRef]

12. Tesfahun, W. A review on, Response of crops to paclobutrazol application. Cogent Food Agric. 2018, 4, 1525169. [CrossRef]

13. Fan, Z.X.; Li, S.C.; Sun, H.L. Paclobutrazol Modulates Physiological and Hormonal Changes in Amorpha fruticosa under Drought Stress. Russ. J. Plant Physiol. 2020, 67, 122-130. [CrossRef]

14. Iqbal, S.; Parveen, N.; Bahadur, S.; Ahmad, T.; Shuaib, M.; Nizamani, M.M.; Urooj, Z.; Rubab, S. Paclobutrazol mediated changes in growth and physio-biochemical traits of okra (Abelmoschus esculentus L.) grown under drought stress. Gene Rep. 2020, $21,100908$. [CrossRef]

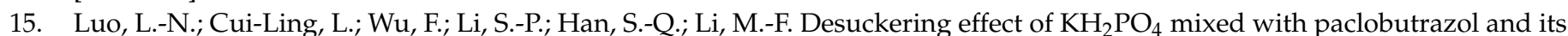
influence on banana (Musa paradisiaca AA) mother plant growth. Sci. Hortic. 2018, 240, 484-491. [CrossRef]

16. Ajmi, A.; Larbi, A.; Morales, M.; Fenollosa, E.; Chaari, A.; Munné-Bosch, S. Foliar paclobutrazol application suppresses olive tree growth while promoting fruit set. J. Plant Growth Regul. 2020, 39, 1638-1646. [CrossRef]

17. Lucho, S.R.; do Amaral, M.N.; Milech, C.; Bianchi, V.J.; Almagro, L.; Ferrer, M.A.; Calderón, A.A.; Braga, E.J.B. Gibberellin reverses the negative effect of paclobutrazol but not of chlorocholine chloride on the expression of SGs/GAs biosynthesis-related genes and increases the levels of relevant metabolites in Stevia rebaudiana. Plant Cell Tissue Organ Cult. 2021, 146, 171-184. [CrossRef]

18. Wang, W.D.; Wu, C.Y.; Lonameo, B.K. Toxic effects of Paclobutrazol on developing organs at different exposure times in zebrafish. Toxics 2019, 7, 62. [CrossRef] [PubMed] 
19. Kumar, G.; Lal, S.; Bhatt, P.; Ram, R.A.; Bhattacherjee, A.K.; Dikshit, A.; Rajan, S. Mechanisms and kinetics for the degradation of paclobutrazol and biocontrol action of a novel Pseudomonas putida strain T7. Pestic. Biochem. Physiol. 2021, 175, 104846. [CrossRef] [PubMed]

20. Terna, T.P.; Akomolafe, G.F.; Ubhenin, A.; Abok, J. Disease responses of different tomato (Solanum lycopersicum L.) cultivars inoculated with culture filtrates of selected fungal pathogens. Vegetos 2020, 33, 166-171. [CrossRef]

21. Adhikari, P.; Oh, Y.; Panthee, D.R. Current status of early blight resistance in Tomato, An Update. Int. J. Mol. Sci. 2017, 18, 2019. [CrossRef]

22. El-Nagar, A.; Elzaawely, A.; Taha, N.; Nehela, Y. The antifungal activity of gallic acid and its derivatives against Alternaria solani, the causal agent of tomato early blight. Agronomy 2020, 10, 1402. [CrossRef]

23. Panno, S.; Davino, S.; Caruso, A.G.; Bertacca, S.; Crnogorac, A.; Mandic, A.; Noris, E.; Matic, S. A Review of the most common and economically important diseases that undermine the cultivation of tomato crop in the Mediterranean basin. Agronomy 2021, 11, 2188. [CrossRef]

24. El-Ganainy, S.M.; El-Abeid, S.E.; Ahmed, Y.; Iqbal, Z. Morphological and molecular characterization of large-spored Alternaria species associated with potato and tomato early blight in Egypt. Int. J. Agric. Biol. 2021, 25, 1101-1110. [CrossRef]

25. Henning, R.G.; Alexander, L.J. Evidence of existence of physiologic races of Alternaia solani. Plant Dis. Rep. 1959, 43, 298-308.

26. Berova, M.; Zlatev, Z. Physiological response and yield of paclobutrazol treated tomato plants (Lycopersicon esculentum Mill.). Plant Growth Regul. 2000, 30, 117-123. [CrossRef]

27. Misu, H.; Mori, M.; Okumura, S.; Kanazawa, S.-I.; Ikeguchi, N.; Nakai, R. High-quality tomato seedling production system using artificial light. SEI Tech. Rev. 2018, 86, 119-124.

28. Seleguini, A.; Júnior, M.J.A.F.; Benett, K.S.S.; Lemos, O.L.; Seno, S. Strategies for tomato seedlings production using paclobutrazol. Semin. Agric. Sci. Londrina 2013, 34, 539-548. (In Portuguese) [CrossRef]

29. Bene, K.S.S.; De Araújo Faria, M.J.; Bene, C.G.S.; Seleguini, A.; Lemos, O.L. Use of paclobutrazol in the production of tomato seedlings. Comun. Sci. 2014, 5, 164-169.

30. Uçan, U.; Uğur, A. Acceleration of growth in tomato seedlings grown with growth retardant. Turk. J. Agric. For. 2021, 45, 669-679. [CrossRef]

31. Tekalign, T.; Hammes, P. Growth and biomass production in potato grown in the hot tropics as influenced by paclobutrazol. Plant Growth Regul. 2005, 45, 37-46. [CrossRef]

32. Upreti, K.K.; Reddy, Y.T.N.; Shivu Prasad, S.R.; Bindu, G.V.; Jayaram, H.L.; Rajan, S. Hormonal changes in response to paclobutrazol induced early flowering in mango cv Totapuri. Sci. Hortic. 2013, 150, 414-418. [CrossRef]

33. Teto, A.A.; Laubscher, C.P.; Ndakidemi, P.A.; Matimati, I. Paclobutrazol retards vegetative growth in hydroponically-cultured Leonotis leonurus (L.) R. Br. Lamiaceae for a multipurpose flowering potted plant. S. Afr. J. Bot. 2016, 106, 67-70. [CrossRef]

34. Mohammadi, M.H.S.; Etemadi, N.; Arab, M.M.; Aalifar, M.; Arab, M.; Pessarakli, M. Molecular and physiological responses of Iranian Perennial ryegrass as affected by Trinexapac ethyl, Paclobutrazol and Abscisic acid under drought stress. Plant Physiol. Biochem. 2017, 111, 129-143. [CrossRef] [PubMed]

35. Forghani, A.H.; Almodares, A.; Ehsanpou, R.A.A. The Role of Gibberellic Acid and Paclobutrazol on Oxidative Stress Responses Induced by In Vitro Salt Stress in Sweet Sorghum. Russ. J. Plant Physiol. 2020, 67, 555-563. [CrossRef]

36. Mehmood, M.Z.; Qadir, G.; Afzal, O.; Ud Din, A.M.; Raza, M.A.; Khan, I.; Hassan, M.J.; Awan, S.A.; Ahmad, S.; Ansar, M.; et al. Paclobutrazol Improves Sesame Yield by Increasing Dry Matter Accumulation and Reducing Seed Shattering Under Rainfed Conditions. Int. J. Plant Prod. 2021, 15, 337-349. [CrossRef]

37. Kamran, M.; Ahmad, S.; Ahmad, I.; Hussain, I.; Meng, X.; Zhang, X.; Javed, T.; Ullah, M.; Ding, R.; Xu, P.; et al. Paclobutrazol application favors yield improvement of maize under semiarid regions by delaying leaf senescence and regulating photosynthetic capacity and antioxidant system during grain-filling stage. Agronomy 2020, 10, 187. [CrossRef]

38. Roseli, A.N.M.; Ahmad, M.F. In Vitro Evaluation of Paclobutrazol against selected pathogenic soil fungi. J. Trop. Plant Physiol. 2019, 11, 13-21.

39. Desta, B.; Amare, G. Paclobutrazol as a plant growth regulator. Chem. Biol. Technol. Agric. 2021, 8, 1. [CrossRef]

40. Waqas, M.; Yaning, C.; Iqbal, H.; Shareef, M.; Rehman, H.; Yang, Y. Paclobutrazol improves salt tolerance in quinoa, Beyond the stomatal and biochemical interventions. J. Agron. Crop Sci. 2017, 203, 315-322. [CrossRef]

41. Jaleel, C.A.; Gopi, R.; Manivannan, P.; Panneerselvam, R. Responses of antioxidant defense system of Catharanthus roseus (L.) G. Don. to paclobutrazol treatment under salinity. Acta Physiol. Plant. 2007, 29, 205-209. [CrossRef]

42. El-Beltagi, H.S.; Ahmad, I.; Basit, A.; Shehata, W.F.; Hassan, U.; Shah, S.T.; Haleema, B.; Jalal, A.; Amin, R.; Khalid, M.A.; et al. Ascorbic acid enhances growth and yield of sweet peppers (Capsicum annum) by mitigating salinity stress. Gesunde Pflanz. 2022, 74, 1-11. [CrossRef]

43. El-Beltagi, H.S.; Ahmad, I.; Basit, A.; Abd El-Lateef, H.M.; Yasir, M.; Shah, S.T.; Ullah, I.; Mohamed, M.E.M.; Ali, I.; Ali, F.; et al. Effect of azospirillum and azotobacter species on the performance of cherry tomato under different salinity levels. Gesunde Pflanz. 2022, 74, 1-13. [CrossRef]

44. Tsegaw, T.; Hammes, S.; Robbertse, J. Paclobutrazol-induced leaf, stem and root anatomical modification in potato. Hortscience 2005, 40, 1343-1346. [CrossRef]

45. Benhamou, N.; Bélanger, R.R. Benzothiadiazole-mediated induced resistance to Fusarium oxysporum f. sp. radicis-lycopersici in tomato. Plant Physiol. 1998, 118, 1203-1212. [CrossRef] [PubMed] 
46. Siciliano, I.; Gilardi, G.; Ortu, G.; Gisi, U.; Gullino, M.L.; Garibaldi, A. Identification and characterization of Alternaria species causing leaf spot on cabbage, cauliflower, wild and cultivated rocket by using molecular and morphological features and mycotoxin production. Eur. J. Plant Pathol. 2017, 149, 401-413. [CrossRef]

47. Pandey, K.K.; Pandey, P.K.; Kalloo, G.; Banerjee, M.K. Resistance to early blight of tomato with respect to various parameters of disease epidemics. J. Gen. Plant Pathol. 2003, 69, 364-371. [CrossRef]

48. Grover, R.; Moore, J.D. Toximetric studies of fungicides against the brown root organisms, Sclerotinia fructicola and S. laxa. Phytopathology 1962, 52, 876-880.

49. Yadawa, U.L. A rapid and nondestructive method to determine chlorophyll in intact leaves. HortScience 1986, $21,1449-1450$.

50. Aebi, H. Catalase in vitro. Methods Enzymol. 1984, 105, 121-126.

51. Rathmell, W.G.; Sequeira, L. Soluble Peroxidase in Fluid from the Intercellular Spaces of Tobacco Leaves. Plant Physiol. 1974, 53, 317-318. [CrossRef]

52. Ruzin, S.E. Plant Microtechnique and Microscopy, 1st ed.; Oxford University Press: New York, NY, USA, 1999.

53. El-Yamany, W.Z. Genetic, Physiological and Anatomical Response of Some Wheat Crosses to Water Stress. Ph.D. Thesis, Kafrelsheikh University, Kafr El Sheikh, Egypt, 2009.

54. Snedecor, G.W.; Cochran, W.G. Statistical Methods, 8th ed.; Iowa State University Press: Ames, IA, USA, 1989. 